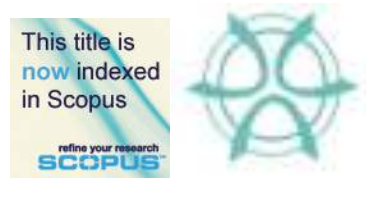

PLANNING MALAYSIA:

Journal of the Malaysian Institute of Planners

SPECIAL ISSUE IV (2016), Page 295 - 314

\title{
EXPLORING THE IMPLEMENTATION AND SUCCESS OF GREEN URBAN MOBILITY IN ASIAN CITIES
}

\author{
Zahid Sultan ${ }^{1}$, Nuhu H. Tini ${ }^{2} \&$ Mehdi Moeinaddini ${ }^{3}$ \\ ${ }^{1,2,3}$ Faculty of Built Environment \\ UNIVERSITI TEKNOLOGI MALAYSIA
}

\begin{abstract}
Urban population is rapidly increasing at the rate of $1.83 \%$ worldwide. This is accompanied by rise in auto-mobile ownership, which conversely imposes adverse environmental, health, economic and social impact in cities. Green Mobility has emerged as the best approach for promoting sustainable and environmental-friendly transportation in modern cities. This paper relied on secondary data to critically review current transport problems, efforts toward ensuring sustainable green mobility, success of the policies and challenges facing the process in Asian cities. The study found that urban transport problems are becoming worst in the cities. However, efforts are in place to reduce car footprint and promote green mobility in the cities. The global overall average score of cities is estimated at $43.9 \%$, while Asia-Pacific cities have $42.8 \%$ average score of green mobility performance. The challenges militating against growth of green mobility in cities include fragmented management, lack of clear vision and strategy for the system, and inadequate infrastructure among others. Integrated and coordinated approach is one of the recommendations made towards ensuring sustainable green mobility in cities.
\end{abstract}

Keyword: Asian cities; Transport impact; Green mobility; Challenges; Sustainability

\section{INTRODUCTION}

Urban population is rapidly increasing at the rate of $1.84 \%$ worldwide. Currently, urban population accounts for $54 \%$ of the total global population, a rise from $34 \%$ in 1960 . It keeps on growing with about 60 million people moving into cities and urban areas every year; approximately over one million every week (Lee et al 2010; WHO, 2015). Projection shows that by 2050 about $70 \%$ of world's population will live in cities. Asia and Africa are the most urbanising regions worldwide. Today, 15 of 27 largest cities in the world are in Asia. Moreover, Asian urban population is predicted to exceed rural population by 2022 (Brinkhoff, 2012; Kapsch, 2013; Lohani, 2014). Such population explosion is accompanied by rise in auto-mobile ownership which conversely imposes adverse environmental, health and social impacts. This in turn generated tremendous concern and desire to seek for means of combating such effects in cities.

Expanding the capacity and building more roads were initially envisaged as sole means of overcoming effects of urban transportation and meeting the demand for accessibility and mobility. But this stimulated more growth in car ownership and usage; resulting to ever-increasing congestion, pollution and environmental degradation. This 
Zahid Sultan, Nuhu H. Tini \& Mehdi Moeinaddini

Exploring the Implementation and Success of Green Urban Mobility in Asian Cities

prompted agitation for urban sustainability - a term referred to as sustainable cities, smart cities, zero-energy cities, low-carbon cities or eco-cities (Hawley, 2014). The concept entail that cities should be made "user-friendly, safe and healthy for habitation through improving mobility - sustainable transportation; a term also known as 'Sustainable Mobility,' 'Green Transportation,' or 'Green Mobility.' Evans (2011) defines Green Urban Mobility as a 'means of creating flexible, responsive, safe, affordable and efficient mobility in cities with less traffic, travel and effort while ensuring environmental sustainability.' In other words, it means giving much priority to public transport, goods vehicles, pedestrians and non-motorised vehicles which ensures that transport system is made accessible for all and sundry (Midgley, 2011).

In the last few decades, concern and interest has been geared towards promoting sustainable mobility in cities globally. Emphasis lies on provision of public transport, cycle paths, health and safety awareness campaign, development of bike-sharing schemes, and facilitating cycling and electric car sharing as alternative mode of transport for short-distance trips. The private sector focuses on sustainable schemes, such as Company Vehicles Sharing and development of innovative technologies such as ebikes (Electric Bikes) and provision of vehicles and infrastructures. Other measures are redistributive schemes like clean docking stations; smartcard integration with public transit; fleet monitoring and integrated fare schemes such as GPS/GNSS tracking and touch screen kiosks (GSM, 2015). This paper looks at urban green mobility in Asia with specific examples drawn from East and Southeast Asian cities. It highlights current transport problems, green mobility practices, success of the policies and factors militating against growth of green mobility in the cities.

\section{URBAN TRANSPORTATION PROBLEMS IN ASIAN CITIES}

Asian mega-cities face numerous and ever increasing urban transport problems. Such include rapid growth in number of motorised and non-motorized vehicles. For example, between the year 2000 and 2010, Singapore's car population increased at $3.4 \%$ per year, of which $1.2 \%$ were motor cycles and scooters (LTASG, 2010). In Laos, motorcycle increased at 13\% per annum before 1997 and later stabilized at 9\% (Chin, 2013). In Cambodia, motorization accelerates at 7\%. About 52,000 cars are added onto Bangkok streets monthly (The Nation, 2010). In Philippines, the rate of private vehicles grew rapidly from 4,558,727 in 2007 to 5,216,646 in 2009; an annual growth rate of 7\% (LTOPH, 2010). In Myanmar, the number of cars grew at a steady rate of $5.2 \%$ per year between 2004 and 2008 while motorcycles increased at $0.8 \%$ per year before 2007 (Chin, 2013) In Shanghai, private car ownership increased from 12 million in 2003 to 93 million in 2012 (Ding, 2014).

Growth in population of vehicles generates various social and environmental problems in Asian cities. Such comprise increased congestion, travel time, fuel consumption, pollution, accident, road rage, inadequate parking space and loss of worker productivity (Pai, et al 2014).

Mix operation of pedestrians, motorized and non-motorized vehicles is a major characteristic of roads in Asian cities. Inevitably instigating disorder and confusion, which hinder smooth flow of traffic and limits efficiency of road network. This generates safety problem to other road users and also contribute to air and noise pollution in the cities (Chin, 2013). 
Another critical transport problem is traffic congestion. Jakarta (Figure 1) ranks number one of the ten top traffic congested cities across the globe (wsj.com, 2015). Bangkok ranks eighth among the top ten worst gridlocks worldwide (Siemens, 2014). As a result countless hours and billions of dollars worth of fuel and productivity are lost to traffic jam yearly. In 2011, traffic congestion costs in Jakarta city was estimated at Rp 46 trillion (US\$5 billion) per year. The costs of wasted fuel, productivity lost and trafficinduced health problems resulting from traffic congestion is estimated at Rp 28.1 trillion each year in Jakarta (Adiansyah, 2012).

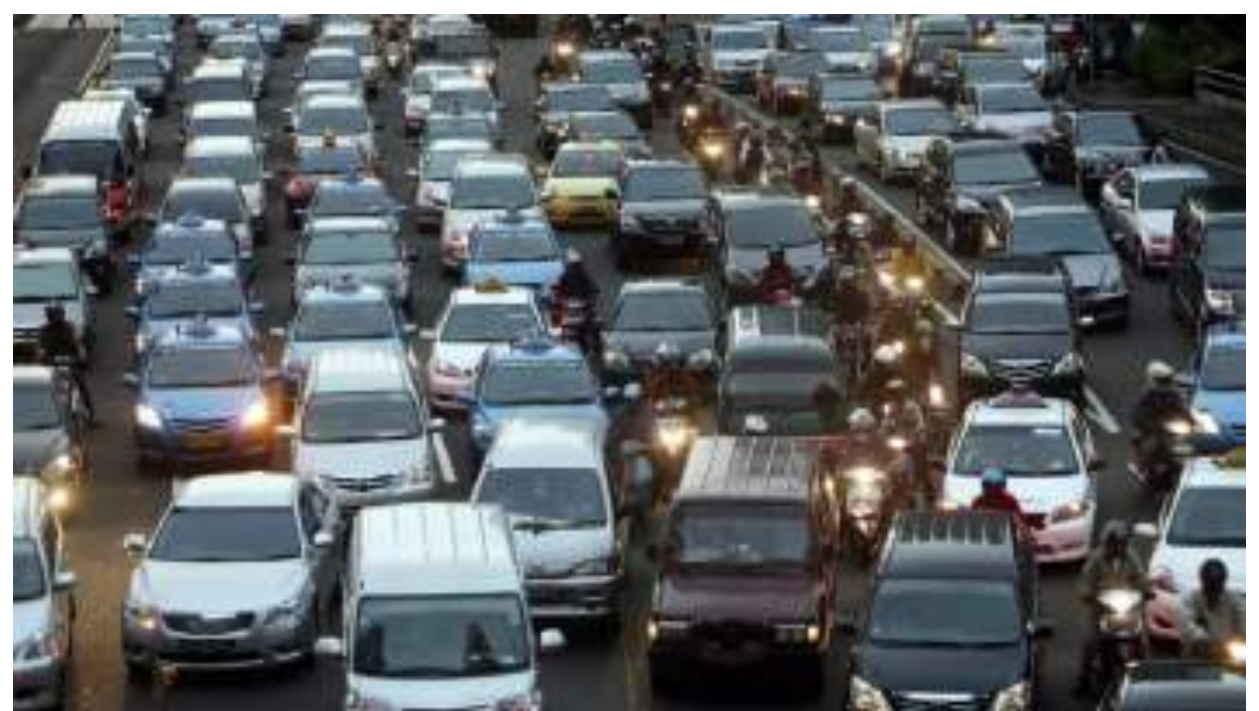

Figure 1: Traffic Congestion with Mixture of Cars and Motorcycles in Jakarta City, Indonesia

Source: http://qz.com. Retrieved 19/05/2015

Personal safety and public health are threatened by the operation of non-motorized vehicles in Asian cities. In Singapore, non-motorized vehicle users accounted for 9.3\% of total people killed and 5.3\% of total injuries in traffic accidents in 2009. Likewise, in Bandung, Indonesia, about $21 \%$ of bikecab users sustain injury during accidents at least once in life (Chin, 2013). In Indonesia, Malaysia and Thailand, cyclists account for $6 \%$ to $7 \%$ of all road traffic deaths while $47 \%$ pedestrians experience accident. In Taipei, about $54.5 \%$ fatalities from traffic accident are generated by motorcycles (Chang, 2012; Chin, 2013).

Motorised vehicles equally account for high traffic accident in Asian cities. For instance, in 2005 Phnom Penh, Cambodia registered 105,800 car accidents and 380,000 motorcycle accidents. The figure increased to 122,800 cars and 448,000 motorcycle accidents in 2006. In Yangon, Myanmar, a total of 2,498 injuries and 208 deaths were recorded from road accidents in 2008 (Chin, 2013). In Taiwan, motorcycles constitute $80 \%$ of fatality and $90 \%$ of injury cases in traffic accident (Pai, et al 2014). China is listed among the highest contributors to world's traffic fatalities. With only $3 \%$ of the world's vehicles, China accounts for $24 \%$ of the world's traffic fatalities. In 2011 , road fatalities 
Zahid Sultan, Nuhu H. Tini \& Mehdi Moeinaddini

Exploring the Implementation and Success of Green Urban Mobility in Asian Cities

amounted to 62,387 , of which $28 \%$ were motorcycle users. The mortality rate from traffic accident was 8.7 per 100,000 people in urban areas. Traffic accident cost Chinese economy about $\$ 21$ billion per annum (Ding, 2014).

Emission from road transportation system is another matter of serious concern in the cities. Transport sector contributes high rate of carbon emissions in cities. For instance, between 1980 and 2005, Philippines and Viet Nam transport sector carbon emission accelerated from $15 \%$ to $37 \%$ and $14 \%$ to $25 \%$, respectively. In Malaysia, the emission remained steady while in Indonesia and Thailand it respectively declined from $26 \%$ to $22 \%$ and $28 \%$ to $26 \%$ (Timilsina and Shrestha, 2009). High energy consumption is generated by rapid increase in motorised and non-motorised vehicles in Asian cities. Figure 2 below shows Riyadh as the highest and Ho Chi Minh City as the lowest in private passenger transport energy consumption.

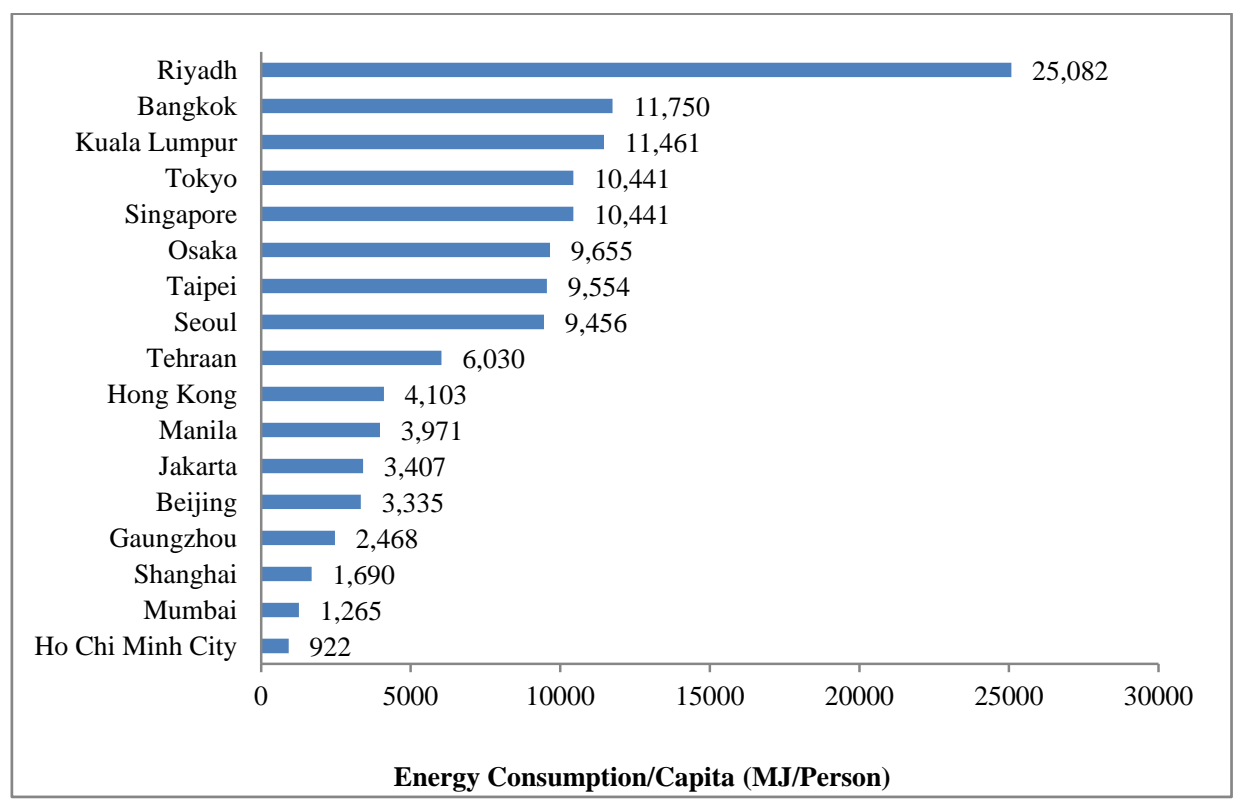

Figure 2: Private Passenger Transport Energy Consumption Per Capita in Asian Cities Source: Kenworthy, 2013

The 'units of energy required per unit GDP created is known as transport energy intensity' (Chin, 2013). This unit is estimated to determine energy consumption of transport sector. In 2005, Malaysia had the highest transport energy intensity; estimated at 53 kilotons oil equivalent per billion US\$. This was followed by Thailand with 38; Indonesia, 34; Viet Nam, 28 while Philippines had the least, about 22 kilotons oil equivalent per billion US\$ (Timilsina and Shrestha, 2009). In 2009, Singapore had an estimate of 37 kilotons oil equivalent per billion US\$ (Chin, 2013). With subsequent rise in vehicle ownership, energy consumption in these countries is assumed to have increased by now. Fuel consumption is often considered as a direct measure of carbon emission. Road vehicles consume more fuel than any other mode of transport. For instance, in Thailand, transport sector use about 25.4 billion litres of fuel yearly, of which road-based 
vehicles consume over $99 \%$. The transport sector energy demand for Thailand is projected to 64.7 megatons oil equivalent in 2050, a rise of $2.5 \%$ from 1995 (Chin, 2013). In Manila, tricycles alone use about US\$5 billion of fuel every year (Maslog, 2015). Such high fuel consumption cost countless billions of dollars, generates air pollution and threatens the health and comfort of urban dwellers.

Significant reduction in urban air quality (Figure 3 ) is recently experienced due to increase in vehicle ownership and over dependence on motor vehicles in the cities. Three of the top five carbon dioxide emitting and 11 of the 20 most polluted cities in the world exist in Asia (ADB, 2015). About 16 of the world's 20 cities with the worst air quality are in China. In Vientiane, Laos, rise in number of vehicles has resulted to decline in air quality. In Bangkok, diesel trucks, two-stroke motorcycles and outdated bus fleets significantly contribute to air pollution. In Cambodia, vehicle emission generates serious environmental degradation, health hazard and retard economic growth (Chhoeurn, 2007; Chin, 2013).

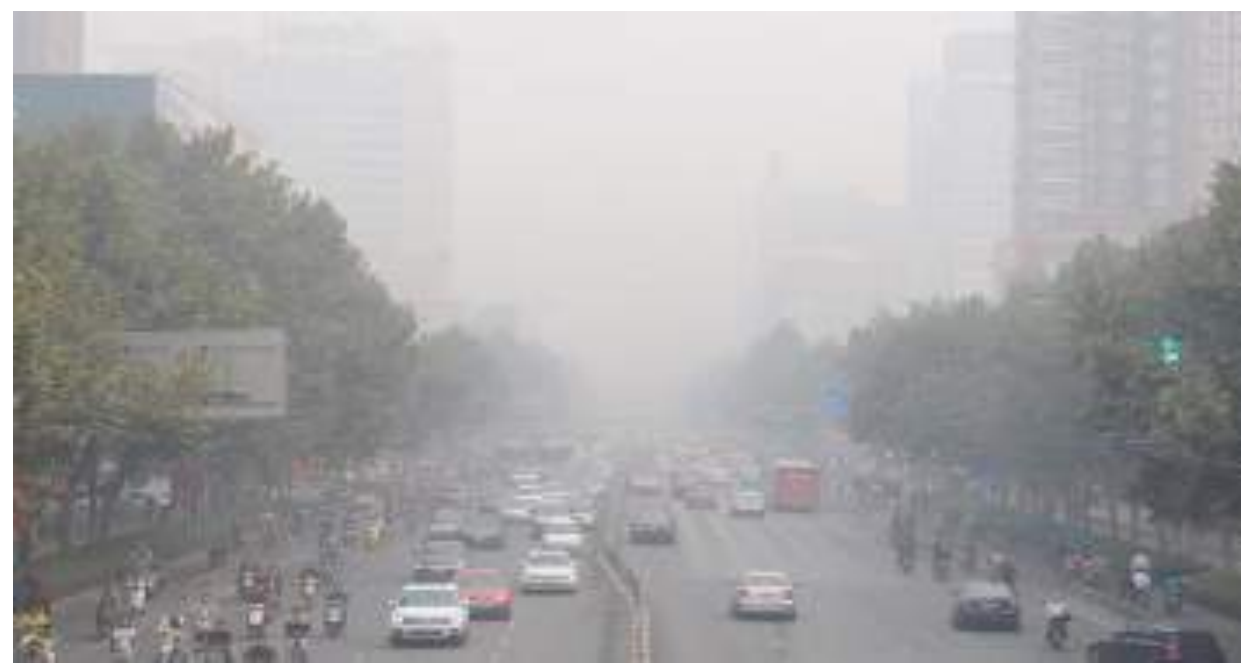

Figure 3: Air Pollution in Zhengzhou City, China Source: chinadaily.com.cn Retrieved 19/05/2015

Noise pollution is also a menace in Asian cities. For instance, in Vientiane, Laos, noise level range from $79.5 \mathrm{~dB}$ to $85.0 \mathrm{~dB}$. This is more than the international norm of 70dB. In Bangkok, noise level along overcrowded roads is between $70 \mathrm{~dB}$ to $85 \mathrm{~dB}$ all round the clock. In Viet Nam, noise pollution from transport is said to be a serious urban concern which needs an urgent attention (Truc, 2003; Schwela and Wele, 2009; Chin; 2013). Shortage of parking spaces is experienced in most cities. In Beijing, there are 2.7 million parking spaces against 5.3 million motor vehicles. Shanghai has $780 \mathrm{k}$ parking slots serving 2.6 million vehicles. Chongqing city has shortage of $190 \mathrm{k}$ parking spaces with deficit growing by 400 spaces daily. Estimate of parking fees account for over 1/3 of the annual costs of owning a car in the city. Hence, roadside parking has become a common phenomenon while others use open-air and playground as parking slots (Meilhan, 2014). Manifestation of the aforementioned phenomena and desire to curtail 
Zahid Sultan, Nuhu H. Tini \& Mehdi Moeinaddini

Exploring the Implementation and Success of Green Urban Mobility in Asian Cities

their consequences led to agitation for practice of green urban mobility as discussed in the next section.

\section{PRACTICE OF GREEN URBAN MOBILITY IN ASIAN CITIES}

\section{Non-motorized Transport}

The commonest strategy used to curtail consequences of urban transport system is promoting cycling and walking. Figure 4 shows the percentage of daily trips by Nonmotorized transport mode in Asian Mega-cities. Shanghai is the highest while Riyadh is the lowest city using non-motorized transport system.

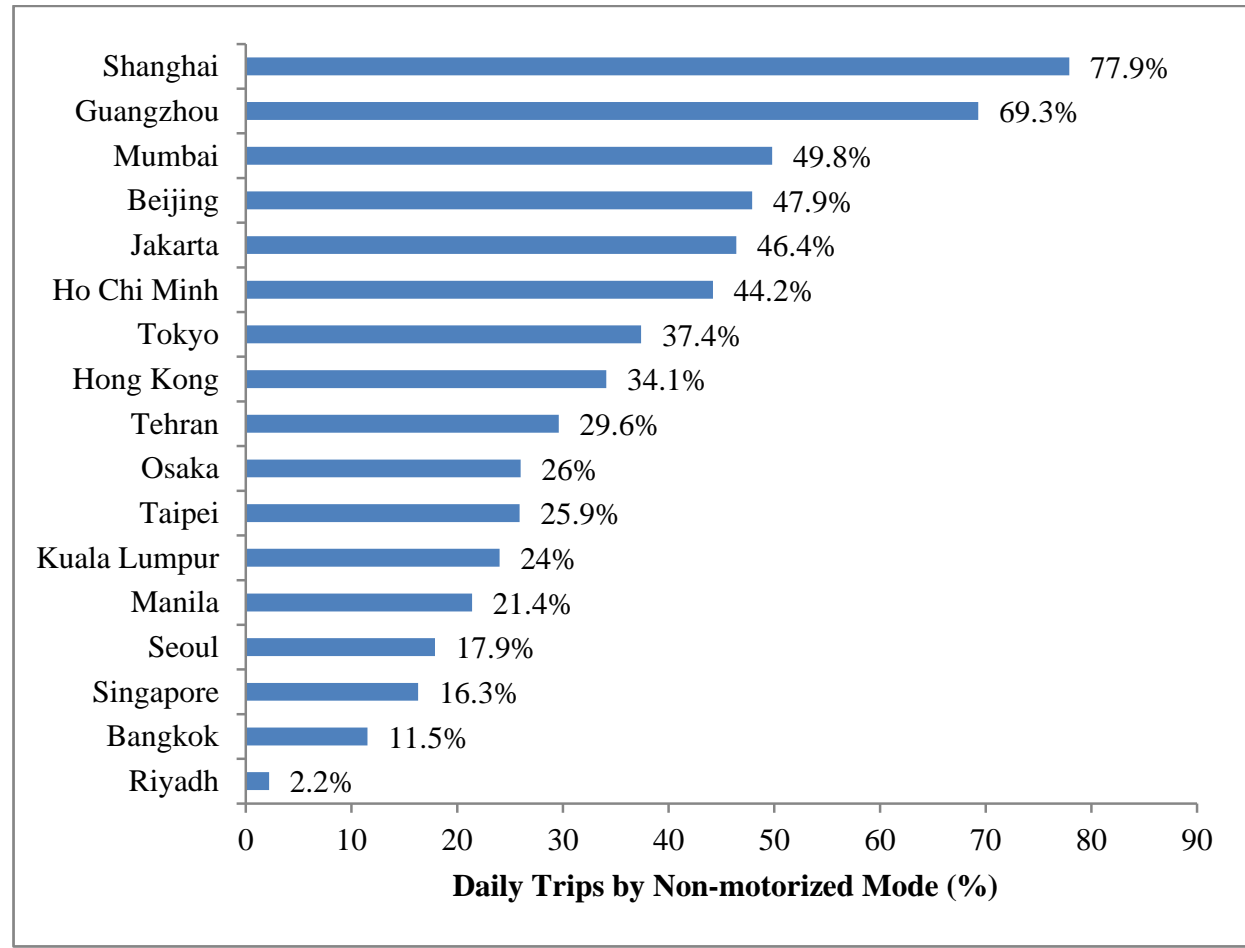

Figure 4: Share of Trips by Non-motorized Transport Mode in Asian Cities Source: Kenworthy, 2013

Several reasons led to encouragement of cycling and walking in the cities. For instance, Sibu city in Sarawak introduced pedestrian network to link the town's bus terminal. This is aimed at reducing traffic congestion and to encourage use of public transport and cycling. (Tseu, 2006). In Melaka city, walkways in historic neighbourhoods are preserved and restricted from automobiles (Figure 5). This protects culture and history of the city besides making it more liveable. Similarly, in Hue city, Viet Nam, historic colonial districts are preserved and revitalized to serve as walkability area and tourist site (ADB, 2015). Vientiane, Laos plan to improve walking and cycling from 200,000 trips to 
300,000 trips in 2007 and 2025 respectively, with annual growth rate of $2.3 \%$ (Toda, 2008).

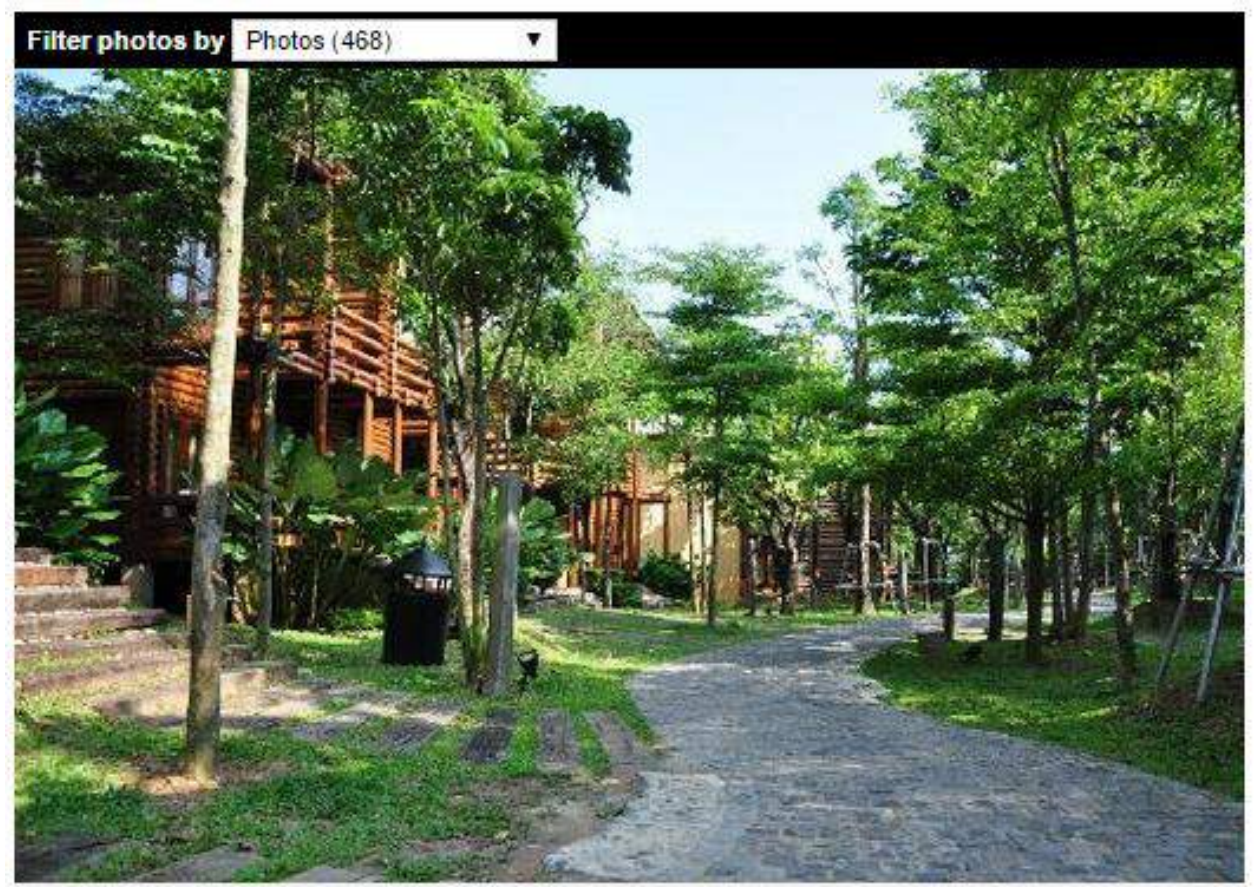

Figure 5: Melaka Neighbourhood Walkway Source: Chiang, 2013

Cycling is an environmentally friendly, cost-effective, healthy and emission-free means of transport, which provides door-to-door service (Mbuya and Guni, 2011). Asian region is the fastest growing bike-sharing market in the world (Shaheen, et al 2010). The largest and most famous bike-sharing program in Asia is the Public Bicycle system in Hangzhou. The system started operating with 40,000 bicycles and 1,600 stations (Shaheen, et al 2010). Number of bicycle rent in the city doubled from 3.5 million in 2009 to 7 million in 2012. In turn, this system has reduced Carbon dioxide emission estimated at 350 Kilo tonne between 2009 and 2012 in the city (Meilhan, 2014). With 5,500 bicycles, Guangzhou bike-sharing system give people wide array of choices to move easily throughout the dense city (Mullich, 2011). Other cities with bike-sharing programmes are Beijing having 21,000 bikes, Taipei 500, Nubija 430, Tianjin and Suzhou.

\section{Public Motorized Transport}

Public transport has become popular mode of transportation in Asian cities. For instance, bus fleet in Philippines increased at 3.4\% yearly from 1990 to 2007 (Sheila, 2010). Likewise in Myanmar, between 2004 and 2008, the number of buses increased at 2.3\% per year to match the increase in patronage (Chin, 2013). Figure 6 shows the percentage 
Zahid Sultan, Nuhu H. Tini \& Mehdi Moeinaddini

Exploring the Implementation and Success of Green Urban Mobility in Asian Cities

of daily trips made by public transport mode in Asian Mega-cities. Manila ranks highest while Riyadh is the lowest in share of public transport mode.

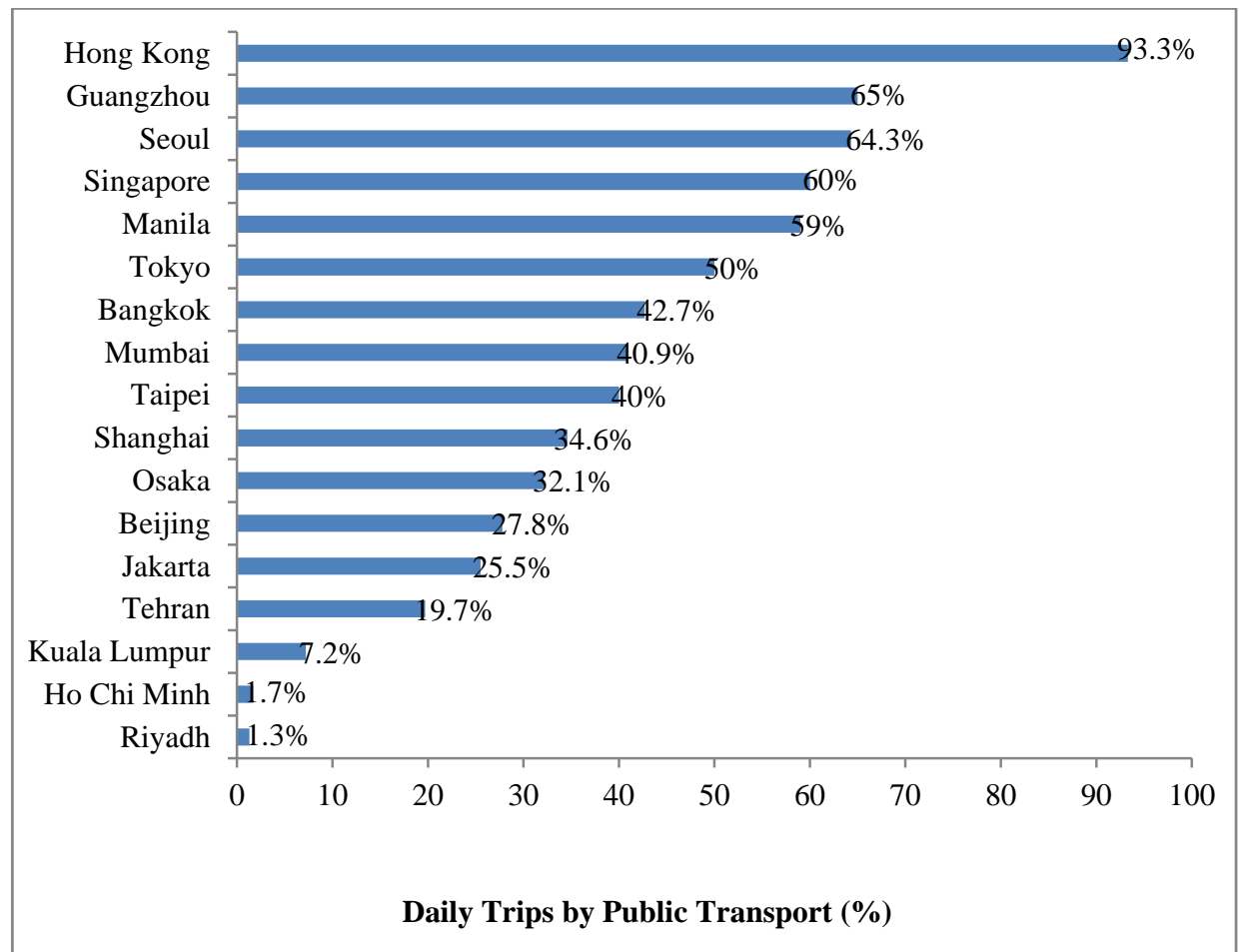

Figure 6: Percentage of Daily Trips by Public Transport Mode in Asian Cities Source: Andreasson, 2011; UNDESA, 2012; Cheong \& Loh, 2013; Kenworthy, 2014; Pai et al, 2014

\section{Bus Rapid Transit}

Bus Rapid Transit (BRT) is 'high-quality bus-based transit system which delivers fast, comfortable, and cost-effective urban mobility'. Irigolen and Dalkmann (2015) observe that BRT and bus priority systems enhance traffic safety and as well improve the health of city residents by reducing air pollution and increasing rates of physical activity, which manifest in longevity and quality of life. BRT is implemented in cities to promote overall transport efficiency (Midgley, 2011). Guangzhou Bus Rapid Transit system with 805,000 daily boarding is the largest ridership of bus corridor in Asia (Figure 7). About 12,000 passengers commute per hour; almost $42 \%$ of personal trips in Delhi (India) are made by BRT (Kogdenko, 2011). In Seoul, BRT initially serviced over 2.1 billion people yearly; but daily average later rose to 9.83 million passengers. This led to improvement in air quality with about $58 \mu \mathrm{g} / \mathrm{m} 3$ reduction in ambient concentration of pollution particles in 2005 (Seoul metropolitan Government, 2006). The BRT in Beijing conveys about 100,000 commuters daily (Mackett, et al 2013).

In Jakarta, Indonesia 'Trans-Jakarta Bus-way' was initiated on 15 January 2004. As a result, $20 \%$ of bus-way users forfeited private cars. The ridership subsequently 
increased to 46,000 passengers per day. Currently, Jakarta BRT ridership is 350,000 passengers daily (ITDP, 2013). In Bangkok, 50\% of passenger trips are conveyed with buses, increasing to $75 \%$ during peak hours. Cities like Metro Manila (Philippines), Phnom Penh and Siem Reap (Cambodia) have scheduled buses as major means of public transport. In Yangon, the bus system makes 19,000 trips/ day serving 4.4 million persons per day (Chin, 2013).

The major drawback of public transportation is inadequacy of service compared to mobility demand by public in most cities. The stops are often characterised by inefficient services, irregular arrival, long waiting time and overcrowding. In turn, this often results to theft, mugging, harassment and other forms of delinquencies (Baedeker and Huging , 2012).

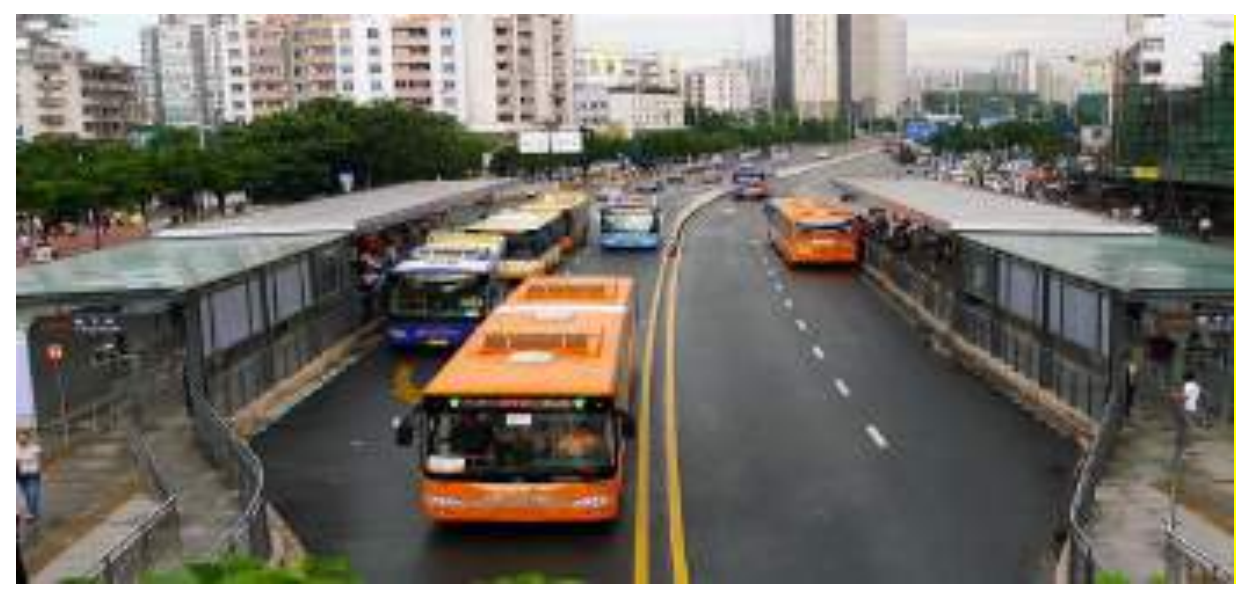

Figure 7: Bus Rapid Transit (BRT) in Guangzhou, China Source: Simes, 2011

\section{Mass Rapid Transit}

Urban rail, known as mass rapid transit (MRT) is an emerging public transport system in Asian cities (Ely, 2012). Shanghai has the longest metro network at $425 \mathrm{~km}$ worldwide, serving 2.1 billion passengers in 2011. Next to it in Asia is Beijing, followed by Seoul and Tokyo. Singapore MRT system serves 2.3 million passenger trips a day since 2011 (Ely, 2012). Bangkok's overhead Sky-train and underground subway system account for 450,000 and 210,000 daily passenger trips respectively (Siemens, 2013). Initially, the two light rail lines in Manila were conveying 500,000 passengers daily. But patronage of the light rail transit (LRT) rose by $29 \%$ within a year - 118 million to 147 million passengers in 2004 and 2005 respectively (Chin, 2013). Subsequently, it conveyed 20\% yearly and settling 372 million passengers in 2010 (Chua Co, 2011). Malaysia proposes to complete over 100 kilometres of new subway lines by 2020 to link Kuala Lumpur with the suburbs. By 2016, trains are expected to operate on new 51-kilometer route connecting the northwestern and south-eastern parts of the city (Siemens, 2014). 
Zahid Sultan, Nuhu H. Tini \& Mehdi Moeinaddini

Exploring the Implementation and Success of Green Urban Mobility in Asian Cities

\section{Emission Control}

Control of emission at the source from vehicle is gaining ground in Asian countries. Thailand has banned leaded gasoline. In Manila, maximum hydrocarbon emissions from vehicles operating in urban areas is set at 7,800 parts per million (EMB, 2004). Table 1 presents percentage of sulphur content in diesel fuel for some Asian countries. Singapore, with maximum of $0.005 \%$ is the most stringent against sulphur content in diesel (NEA, 2013). Next to it is Thailand as indicated on table 1 below. The major problem with emission control is inadequate implementation strategy. Although city like Singapore has installed video camera to capture smoky vehicles, most cities lack well coordinated institutions to inspect and execute vehicle users defaulting emission control regulation.

Table 1: Standard for Diesel Sulphur Content in Some Asian Countries

\begin{tabular}{|l|l|l|}
\hline Country/Area & Year of Implementation & $\begin{array}{l}\text { Diesel's Sulphur Content } \\
(\mathrm{wt} \%)\end{array}$ \\
\hline Japan & 2000 & 0.05 \\
\hline Taiwan & 2000 & 0.05 \\
\hline Thailand & 2002 & 0.035 \\
\hline Manila & 2004 & 0.05 \\
\hline Malaysia & 2005 & 0.05 \\
\hline Myanmar & Unknown & 0.02 \\
\hline Viet Nam & 2007 & 0.05 \\
\hline Singapore & 2006 & 0.005 \\
\hline
\end{tabular}

Source: http://www.unep.org/, 2011; Chin, 2013

Legislative measures such as Vehicle engine management, inspection and maintenance, roadside monitoring and regulation on noise level is promoted to reduce environmental effect of urban transport in some cities. In Bangkok, cars use catalytic converters; almost $80 \%$ of motorcycles operate on less polluting four-stroke engines while smoky vehicles are inspected daily (Chin, 2013). In Manila city, emission violators are fined and the fund is used for Air Quality Management such as research, restoration, outreach, technical assistance and for regulatory activities on air pollution control (Krupnick et al., 2003). Malaysia has introduced measures to reduce air pollution from mobile sources. Singapore conducts chassis dynamometer smoke test in vehicles to ensure free acceleration. Myanmar adopts maximum noise level of $115 \mathrm{~dB}$ as a measure for traffic noise management (Chin, 2013). In Taipei city, air pollution is controlled from mobile source by encouraging use of low emission vehicles and enhancement of testing and elimination of high pollutant vehicles. Educating the public to periodically examine and maintain vehicles according to Bureau of Environmental Protection regulation is another strategy (Schwela and Wiele, 2009).

\section{Alternative Clean Energy}

Use of environment-friendly fuel options - alternative clean energy or bio-fuel is encouraged in some cities. In Phnom Penh, price of gas has been subsidized half that of petrol to encourage taxi operators and private car owners convert their engines and use gas. The use of gas alternative fuel for transport system is promoted in Bangkok while use of natural gas vehicles is encouraged in Ho Chi Minh and Kuala Lumpur (Chin, 2013). Manila has about 10,000 while Malaysia own 30,600 natural gas motor vehicles. Malaysia 
has also introduced ENVO Diesel - containing 5\% palm oil and 95\% petroleum diesel, emitting less nitrogen oxides, carbon monoxide and hydro-carbon (Kalam and Masjuki, 2011). Ho Chi Minh City adopts 'environmentally sustainable measures such as conversion of street lamps to less-polluting and more energy-efficient (LED) light emitting diode' (Chin, 2013).

\section{Traffic Management}

The major approach used for Traffic management is separating motor vehicles from nonmotor vehicles by prioritising and dedicating lanes for buses and bikes. Development of bus lane in Kunming city, China attracted 50\% rise in buses using the corridors and about 8,000 hourly passenger trips per lane (Mohan, 2005). Parking restriction is another traffic management strategy. This is implemented in Beijing by weekly 'No Driving Day' prohibiting vehicles with certain last plate number from operating, which is rotated throughout the year. Vehicle Quota System (VQS) is used to manage the growth of vehicle ownership in Singapore, Shanghai, Beijing and Guangzhou (Baedeker and Huging, 2012). In Peninsular Malaysia and Singapore, electronic ticket is used for online booking and payment of intercity public transport system (Midgley, 2011).

Congestion pricing policy is used to restrict traffic congestion in downtown areas. It involves charging vehicles for entering busier downtown areas; aimed at reducing their number by raising revenue. Three cities reckoned worldwide as where congestion pricing is most successful include Singapore, London and Stockholm. In London, the policy has reduced number of vehicles in city centre by $45 \%$, while in Singapore it is by $33 \%$. Beijing has also implemented congestion pricing, the first Chinese city to do so (Midgley, 2011; Maslog, 2015).

\section{SUCCESS OF GREEN MOBILITY POLICIES IN PROMOTING ECO- FRIENDLY ENVIRONMENT IN ASIAN CITIES}

Green mobility policies are mechanisms used to achieve sustainable transport system in cities. The success incurred by such policies in promoting eco-friendly environment in Asian cities is here highlighted.

Provision of public transportation, subway lines, MRT and BRT lines and bicycle stands has promoted safer transport in some cities. As a result, good number of road users opted to shift from private cars to public transport mode. In Beijing, provision of 7 subway lines and 153 new BRT lines accounted for $39.7 \%$ mobility in 2012 compared to $29.8 \%$ in 2005 (Meilhan, 2014). In Seoul, BRT serve about 9.83 million passengers daily. This led to improvement in air quality with $58 \mu \mathrm{g} / \mathrm{m} 3$ reduction in ambient concentration of pollution particles in 2005 (Seoul Metropolitan Government 2006). New BRT system in Ahmedabad, has succeeded in reducing fatalities on corridors by 55\% (Welle, 2014). Guangzhou BRT has reduced Carbon dioxide emissions by 45,000 metric tons (Colins and Shu 2012). In Hangzhou, China, increase in bicycle rent succeeded in reducing carbon dioxide emissions of 370 Kilo tonnes between 2009 and 2012 (Meilhan, 2014).

Traffic management policies are successful in some of the cities. In Singapore, road pricing scheme has raised proportion of people travelling to workplace by public transport from 46\% to $67 \%$ in 1975 and 1998 respectively (Baedeker and Huging, 2012). Dedicated lanes for buses and bicycles are also improving urban mobility in some cities. In Kunming city, bus lane system has raised public transit mode share from $6 \%$ to $24 \%$ 
Zahid Sultan, Nuhu H. Tini \& Mehdi Moeinaddini

Exploring the Implementation and Success of Green Urban Mobility in Asian Cities

in 1999 and 2010 respectively. Average waiting time for bus has decreased by 59\%, while bus lane capacity accelerated from 2,000 commuters per hour per direction to 7,500 (Meilhan, 2014). In Taipei, the system has reduced number and severity of road accident ((Schwela and Wiele, 2009). In Seoul, replacement of Cheonggyecheon highway with riverfront, walkways and public squares has drastically curtailed traffic congestion featuring eco-friendly scenery in the territory (Replogle and Kodransky, 2010).

The use of electric vehicle, incentives and tax reduction on purchase of electric vehicles is gaining ground in Asia. This resulted to $80 \%$ purchase of new electric vehicles comprising hybrid, electric, natural gas and fuel cells in some Chinese cities, 2012. The sales of electric cars rose by 32\% from 12,791 in 2012 to 17,642 in 2013 (Meilhan, 2014). In Singapore, number of green vehicles increased from 140 to over 1500 in 2005 and 2007 respectively. As a result, fleet composition is curtailed which enhance fuel economy and reduce air pollutant emissions in the city (GFEI, 2010).

Implementation of vehicle quota system through new car plate license has resulted to decline in car sales. This in turn limited growth of car usage in Singapore and Shanghai (Baedeker \& Huging, 2012). Similarly, Beijing and Guangzhou recorded 52\% and 30\% drop in car sales respectively in 2012. In consequence, Guangzhou experienced $60 \%$ increase in patronage of public transportation, while Beijing had $25 \%$ reduction of emissions from motor vehicles (Meilhan, 2014).

Parking fees encourage private car users to shift to other modes of mobility which reduces vehicle ownership in cities (Baedeker and Huging, 2012). In Beijing, higher parking fees in non-residential areas have resulted to $12 \%$ decline in traffic volume and 25-35 minutes reduction in traffic jam within central areas.

Restriction on circulation of motor vehicles and motorcycles reduce traffic congestion and air pollution level in some of the cities. The nationwide restriction on motorcycle circulation in urban areas of China is yielding positive outcome. In Foshan city, the policy resulted to decline in use of motorcycle for urban transport from $38.6 \%$ to $19.7 \%$. In Guangzhou motorcycle related accidents decreased by $20 \%$ while death reduced by $8 \%$. Kunming city experienced $35 \%$ decline in death caused by motorcycles. In Beijing, restriction of car usage based on odd and even plate numbers reduce about 800,000 vehicles from operating daily, a fall in traffic volume by $19.5 \%$, speed on roads has improved by $15 \%$ while PM10 emissions is curtailed by $7 \%$ (Replogle and Kodransky, 2010; Meilhan, 2014).

Fuel economy standards reduce oil consumption, air pollution and carbon in the cities. In China, between 2002 and 2006, the standard curtailed fuel consumption of new LDC fleet by $11.5 \%$. In 2012, India recorded increase in fuel economy of $10 \%$ higher than in 2008 . This led to decline of $23 \%$ in fuel consumption related problems due to advancements in engine technology and adaptation of smaller engine capacities in automotive industry (Thakkar and Buresu, 2012).

Little et al (2014) used 19 criteria to assess mobility maturity and performance in 84 cities worldwide. Result of Urban Mobility Index shows a global overall average score of $43.9 \%$. This indicates that most cities are still lagging behind and not adequately equipped to cope with the challenges of urban mobility. Among the regions surveyed, Europe has the highest (42.6\%) score of urban mobility system worldwide. Next are Latin America (43.9\%) and Asia Pacific (42.8\%) cities with slightly below average performance. North America - USA and Canada has (39.5\%) overall performance. Africa 
and Middle East are the lowest performing regions with total averages of $37.1 \%$ and $34.1 \%$ respectively. In regard to individual city performance, Hong Kong is the highest $(58.2 \%)$ globally. Hanoi ranks lowest $(30.9 \%)$ among the cities surveyed in Asia as indicated on figure 8 below.

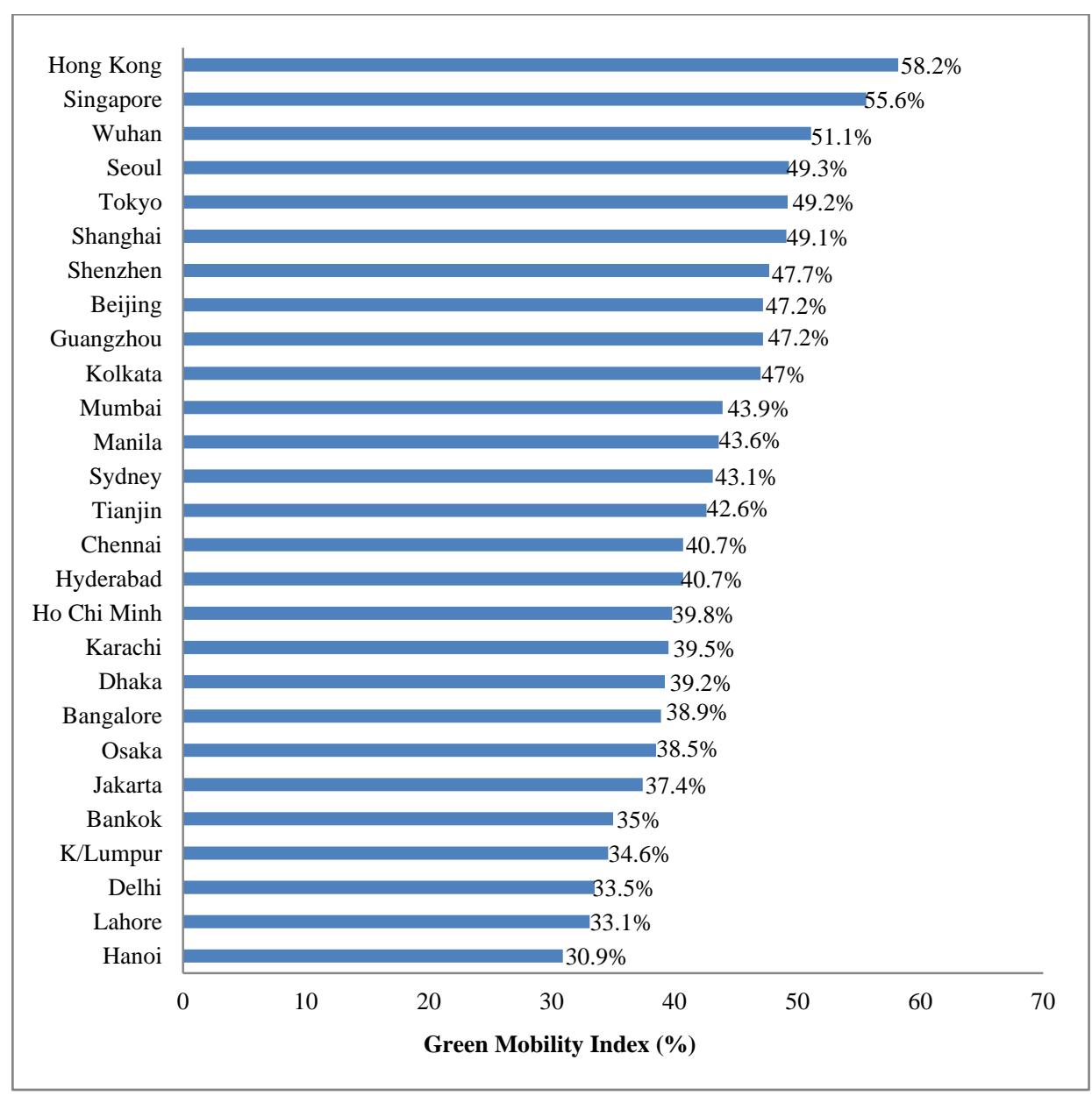

Figure 8: Green Mobility Index of Asian Mega-cities Source: Little et al, 2014

CHALLENGES TO GROWTH OF URBAN GREEN MOBILITY

Lack of clear vision and strategy is a major challenge militating against growth of urban mobility in most cities. This often results to formulation of policies that are incompetent or not compatible with mobility demand of the public. Such policies are either limited in scope or lack clear guidelines for implementation or monitoring of green mobility system.

Absence of coherent and co-ordinated linkage of green mobility policy across the tiers of government and various environmental management sectors is also a hindrance to growth of green mobility system (Hammer, et al, 2011). As a result, mobility strategies 
Zahid Sultan, Nuhu H. Tini \& Mehdi Moeinaddini

Exploring the Implementation and Success of Green Urban Mobility in Asian Cities

are often designed and implemented at city-level without consideration of regional mobility need. This limits optimum interaction and resource exchange at regional level, which is a serious menace to sustainable mobility.

Management of urban mobility is solely operated by city governments. There is no much regard for participation by relevant stakeholders such as environmental management ministries, citizen groups, marketers, transport cooperatives, media, educational and training institutions (Jain, 2013) in deciding transport policies, plans and practices. Hence, the system is managed based on single instead of integrated and collaborative effort seasoned with broader opinion, knowledge, and priorities that would produce efficient policies and implementation strategies. Inadequacy of non-motorized transit and public transport service is another factor retarding growth of green mobility. Most cities do not have provision for pedestrians, cycles and other non-motorised facilities. For example, nearly $90 \%$ of roads in Asian cities have no provision for sidewalk (Jain, 2013). This generates mix operation of pedestrians, motorized and non-motorized vehicles; resulting to disorder, confusion and accident on roads in the cities.

Limited knowledge on environmental and health effects of transport emission make the general public not to comply or obey some traffic legislative and management regulations. Other factors such as lack of standards and weak institutional and enforcement set up to implement policies impede effective implementation of urban mobility policies in most cities (Chin, 2013).

\section{CONCLUSION}

Green Urban Mobility promotes social, economic and environmental friendly transit in modern cities. Socially, it is a basis for realization of social right, gender dignity and equity in the cities. Economically, 'it is a powerful tool for economic growth, poverty reduction, social inclusion and gender empowerment' (Jain, 2013). Hence, all people: men and women, rich and poor, young and old, without any deprivation, desire adequate and equal access to mobility services. It is therefore not out of place that green mobility has recently become a global, regional, national and local interest and agenda. In order to ensure sustainable mobility system, the challenges retarding its growth must be overcome. The following are recommended as basic strategies and way forward.

Green urban mobility system need to have clear and integrated policy designed within national framework. The responsibility of each tier of government should be properly spelt out for efficient guidance. Federal government should set policies; state government should interpret while local government should implement such policies at local level.

Meaningful collaboration and partnership need to be established between public sector, private sector and communities over green mobility agenda; a concept known as 'Public-Private-Partnership' or 'Co-responsibility' approach (Mohanty, 2012). The ability and interest of relevant government or non-governmental stakeholders should be given keen consideration in planning and implementation of green mobility policies.

Government needs to provide dedicated facilities for pedestrians, cycles and other non-motorized transits in cities (Lehmann, 2010). Plans should be made to improve efficiency of public transport, create footpaths and develop urban bicycle and bus lanes in downtowns. Car-sharing and bicycle-renting businesses need to be encouraged. Government should as well initiate policies that will encourage use of energy efficient, 
bio-fuels and low emission vehicles, and create public awareness on the use of green transport modes.

\section{ACKNOWLEDGEMENT}

The authors wish to thank all of those who have supported this research for their useful comments during its completion. In particular, we would like to acknowledge the UTM Management Centre (RMC). The funding for this project is made possible through the research grant obtained from Ministry of Education (MoE) Malaysia under GUP the Universiti Teknologi Malaysia (Grant no: Q.J130000.2721.00K99).

\section{REFERENCES}

ADB (Asia Development Bank) 2015. Green Cities: A Sustainable Urban Future in Southeast Asia - Urban Development Features, January, 2015, Asia Development Bank. http://www.adb.org. Retrieved 13/02/2015.

Adiansyah, Fitrian. (2012). Electing the Leader of Jakarda, the city of (no) joy: Opinion News; Jakarta post, $21^{\text {st }}$ March, 2012 http://www.thejakartapost.com R

Andreasson, Ingmar. (2011). Building a Sustainable Tomorrow with Smart Urban Mobility: Healing our communities. Published by Trans.21 June, 2010 www.airfront.us617-825-2318

http://www.advancedtransit.org/wpcontent/uploads/2011/08/_ Retrieved 30/02/15

Bohler-Baedeker, Susanne and Huging, Hanna. (2012). Urban Transport and Energy Efficiency: Module 5h; Sustainable Transport - a Source Book for Policymakers in Developing Cities. Bonn; Dt. Ges fur Internat. Zusammenarbeit, P 81.

Brasier, A. (2011). Urban Greenways: The Case for the Selmon Greenway. Unpublished M.Sc. Thesis. Department of Geography, Environment, and Planning College of Arts and Sciences: University of South Florida. June, 2011.

Brinkhoff, (2012. The 27 Mega-Cities; The Principal Agglomerations of the World, 201204- 01). European Association of National Metrology Institutes (2013). Mega Cities. http://www.emrponline.eu/call2013/docs/MegaCities.pdf Retrieved 08/10/2015.

Choi, Cheong Chik. and Loh, Nadiah. (2013). Best Practices: Transport Policies and Patterns: Comparison of Five Asian Cities. Journeys. Singapore:Land Transport Authority (LTA) Academy, September 2013. PP 69-78. http://www.lta.gov.sg/ltaacademy/doc/13Sep069.

Chhoeurn, M. (2007). Environmentally sustainable transport in Phnom Penh, Cambodia. Presented at Asian Mayors Policy Dialogue for the Promotion of Environmentally Sustainable Transport in Cities, 23-24 April, Kyoto, Japan.

Chang, Jason. (2012). Q \& A with Chang Jason: Motorized Two-Wheelers in Taipei. Interview by Rebecca Heywood. November 5, 2012. The City Fix Brasil. World Resources Institute. http://thecityfix.com/blog/ Retrieved 08/10/2015

Chiang, J.C. (2013). Central Melaka District Melaka State Vacations. Ayer Keroh TourismOrganization. Trip Advisor. http://www.tripadvisor.com.ph/Tourismg106256 Retrieved 20/05/2015. 
Zahid Sultan, Nuhu H. Tini \& Mehdi Moeinaddini

Exploring the Implementation and Success of Green Urban Mobility in Asian Cities

Chinadaily. (2014). Top 10 Chinese Cities with worst Air Quality. Business / Biz Photos. http://www.chinadaily.com.cn/bizchina/201403/20/content_17358707_10.htm Retrieved 19/05/2015.

Chua Co, Judy D. (2011). Light rail systems gain in 2010. Business World Research, 17 February. Manila, Philippines. http://www.bworldonline.com/Research/economicindicators.php?id=0443

Colin, Hughes and Shu, Xianyuan. (2011). Guangzhou, China Bus Rapid Transit: Emissions Impact Analysis. Institute for Transportation and Development Policy, May 2011. P 3. http:// www.itdp.org/documents/20110810-ITDP-GZBRTImpacts.pdf.

Ely, Mageret. (2012). Urban Rail Networks in World Cities. In Ebrahim, Naleeza, Sun, Goerge, Ely, Mageret, Ai Foo Jong (eds.). Journeys; Sharing Urban Transport Solutions. Land Transport Authority (LTA) Academy ,1 Hampshire Road, Singapore 219428. Issued $8^{\text {th }}$ May, 2012. P 52. http://www.lta.gov.sg/ltaacademy/doc.

EMD. (2004). National Air Quality Status Report (2003-2004). National Air Quality Status Report (2003-2004). Department of Environment and Natural Resources, Environmental Management Bureau, Quezon City, Philippines. http://emb.gov.ph/eeid/publicationfiles/statreport04precontent.pdf. Retrieved 15/03/2015.

Evans, Micheal. (2011). Sustainable Transport. Earth Times News, April 2011. http://www.earthtimes.org/encyclopaedia/environmental-issues/. Retrieved $19 / 02 / 15$.

GSM. (2015). Zero-Emission Mobility: Sustainable Urban Mobility. Green Spider Mobility (online) http://www.greenspider.eu/sustainable-mobility.html. Retrieved 30/1/2015.

GFEI. (2010). Improving Vehicle Fuel Economy in the ASEAN Region. Working Paper1/10, Global Fuel Economy, International Energy Agency, July 2010. P 22. (online)www.globalfueleconomy.org, Retrieved 01/04/2015.

Hawley, Kate. (2014). Transforming Cities for Sustainability: Facts and Figures. Sci. Dev Net (online) http://www.scidev.net/global/cities/feature/ Retrieved 16/02/2015.

Hammer, S., Kamal-Chaoui, L., Robert, A., Plouin, M. (2011). Cities and Green Growth: A Conceptual Framework. OECD Regional Development Working Paper 2011/08. OECD Publishing. P $40 . \quad$ (online) http://dx.doi.org/10.1787/5kg0tflmzx34en..http://www.unep.org/transport/PCFV/PDF/Maps_Matrices. Asia Pacific 50ppm Diesel Sulphur Matrix. September 20 ${ }^{\text {th }}$, 2011. Retrieved 24/05/2015.

ITDP. (2013). Jakarta BRT (Transjakarta): Updated March 14, 2013. Institute for Transportation Development Policy. http://www.worldbrt.net/en/cities/jakarta.aspx. Retrieved 24/05/2015.

Jain, A. K. (2013). Sustainable Urban Mobility in Southern Asia: Regional Study Global Report on Human Settlements 2013. PP 1-25. http://www.unhabitat.org/grhs/2013. 
Icamina, P. (2012). Philippines to Launch 100,000 Eco-friendly E-trikes. Sci. Dev Net 27/11/2012. http://www.scidev.net/global/transport/news/ Retrieved $16 / 02 / 2015$

Irigolen, J. L. \& Dalkmann, H. (2015). Want Healthy, Thriving Cities? Tackle Traffic Safety First: Safe, Clean, Affordable... Transport for Development. 14/01/2015.The World Bank. http://blogs.worldbank.org. Retrieved 03/03/2015

Kalam, M. A. and H. H. Masjuki (2011). Experimental test of a diesel engine using envodiesel as an alternative fuel. In New Trends and Developments in Automotive System Engineering. M. Chiaberge (ed.) InTech Publishers.

Kapsch. (2013). Challenges and Concepts for Urban Mobility in European cities: Smart Cities, Innovation 19.08.2013. (online) follow.kapsch.net. Retrieved 07/02/2015.

King, Ritchie and Kuo, Lily. (2013). Here are the world's worst cities for air pollution, and they're not the ones you'd expect.. Quarz; October 18, 2013. http://qz.com/136606/

Retrieved 19/05/2015.

Kogdenko, N. (2011). Successfulness of Bus Rapid Transit systems in Asia Ex-post Evaluation. Library Report. Energy Research Centre of the Netherlands, February $2011 \quad$ http://www.ecn.nl/docs/library/report/2011/o11013.pdf. Retrived 13/02/15.

Krupnick, A. Morgenstern, R. Fischer, C. et al (2003). Air Pollution Control Policy Options for Metro Manila. Discussion Paper 03-30. Resources for the future, Washington, DC. December 2003. PP 40-47. (online) http://www.rff.org/.

Lee, Rick., Song, Jimmy., Sia, Victor et al (2010).Urban Solutions to City Living in Singapore and the Asian Belt Region. Hitachi Asia Ltd. News Release. Hitachi to Strengthen Social Innovation Business in Asian Belt Zone, May 2010. http://www.hitachi.com/New/cnews/100531a.pdf.

Lehmann, Steffen. (2010). Green Urbanism: Formulating a Series of Holistic Principles. Surveys and Perspectives Integrating Environment and Society Journal. 3.2/ 2010 : VOL.3/ N02. https://sapiens.revues.org.

Little, Arthur D., Audenhove, F., Dauby, L., Korniichuk, O. et al. (2014). The Future of Urban Mobility 2.0: Imperatives to shape extended mobility ecosystems of tomorrow. January, 2014. PP 14-19. (online) http://www.uitp.org. Retrieved 20/03/2015.

Lohani, Bindu N. (2014). Innovative Solutions to Help Asian Cities Grow Green. Climate Action Programme. 22 January. The Asian Development Bank. http://www.adb.org. Retrieved 30/01/2015.

LTASG. (2010). Singapore Land Transport: Statistics in Brief. Land Transport Authority, Singapore. https://www.lta.gov.sg. Retrieved 20/03/2015.

LTOPH. (2010). Number of Motor Vehicles Registered by Classification \& Mode of Registration. Land Transport Office, Philippines. MVC_LTO2009. http://www.lto.gov.ph/Statistics/Stats2009/.

Mackett, Roger L., May D. Anthony, Kii, M. Et al. (2013). Sustainable Transport for Chinese Cities. Transport and Sustainability, V. 3. 
Zahid Sultan, Nuhu H. Tini \& Mehdi Moeinaddini

Exploring the Implementation and Success of Green Urban Mobility in Asian Cities

Emerald Group Publishing Limited, pp $380 \quad$ 16th January 2013, ISBN: 97817819047 ISSN: 2044-9941.

Maslog, Crispin. (2015). Asian-Pacific Analysis: Easing Megacity Congestion. Sci.Dev Net Media. http://www.scidev.net/global/transport/analysis-blog. Retrieved $16 / 02 / 2015$.

Mbuya, F. M. and Guni, E. B. (2011). Road Safety for Cyclists In Urban Areas: A Case Study of Dar Es Salaam. Presented at Annual Roads Convention, Dar es Salaam, Tanzania 17 - 18 November 2011.UWABA Dar Es Salaam Cycling Community.

Midgley, P. (2011). Improving Urban Mobility. Proceedings of AITPM 2011 National Conference Linking Communities: Growing liveability and accessibility. 10 - 11 August 2011.

Meilhan, Nicolas. (2014). Dealing with Urban Mobility Challenges - What can we learn from China? Slide Share. Automotive Business, 10 ${ }^{\text {th }}$ February, 2014. http://www.slideshare.net. Retrieved 23/05/2015.

Mohan, Dinesh. (2005). Public Transportation in Large Cities: State of the Art Transportation Research and Injury Prevention Programme Indian. Institute of Technology Delhi. http://tripp.iitd.ernet.in/delhibrts.

Mohanty, CRC. (2012). Sustainable, Low-carbon and Green Cities; Lessons learnt from UNCRD programmes on EST, 3Rs and IPLA. Presented at the Regional Environmentally Sustainable Transport Forum in Asia under the Asian EST Initiative Third HLS ECS. 6-8 March 2012 Siem Reap, Cambodia. United Nations Centre for Regional Development. http://hls-esc.kitaqcompost.net.

Mullich, Joe. (2011). Breakthroughs in Urban Mobility: Perspective in Sustainable Transport. The World Street Journal. Dow Jones \& Company, Inc. http://online.wsj.com.

NEA. (2013). Air Quality and Targets. National Environmental Agency, Singapore. (online) http://www.nea.gov.sg/. Retrieved 15/03/2015.

Pacudan, M. (1995). Urban Transport Policies: Energy and Environmental Implications: the Asian Experience. Conference Proceedings of European Council for an Energy Efficient Economy. http://www.eceee.org. Retrieved 21/05/2015.

Pai, M., Gadgil R., Mahendra A., et al. (2014). Motorised Two-Wheelers in Indian Cities: A case study of the City of Pune. Working Paper, March 2014. India. Embarg. http://www.wricities.org. Retrieved 20/04/2015.

Replogle, M. and Kodransky M. (2010). Urban Leaders Find Transportation Paths to Global Green Growth. In Journeys: Sharing Urban Transport Solutions, Issue 4/ May 2010. Singapore, Land Transport Authority Academy. P 16. http://www.lta.gov.sg Retrieved 19/04/2015.

Schadea, W., Krail, M., and Kuhn, A. (2014). New mobility concepts: myth or emerging reality?. Transport Research Arena - TRA 2014, 5th Conference - Transport Solutions: From Research to Deployment; Paris, 14 - 17 April 2014. http://publica.fraunhofer.de. Retrieved 19/04/2015.

Schwela, Dietrich and Wiele, Adriaan (2009). Air Quality Management. Module 5a. Sustainable Transport. A Sourcebook for policy makers in Developing Cities. Revised Octorber 2009, GTZ Transport Policy Advisory Services, Germany. P 8. http.//www.gtz.de. Retrieved 15/04/2015. 
Seoul Metropolitan Government. (2006). Seoul Public Transportation Reform: a Brand New Seoul. Seoul. Seoul Metropolitan Government. PP 18-65.

Shaheen, Susan A., Guzman, Stacey., Zhang, Hua., et al. (2010). Bike sharing in Europe, the Americas, and Asia Past, Present, and Future. Presented at Transportation Research Board Annual Meeting. $3^{\text {rd }}$ March, 2010. Institute of Transportation Studies UC Davis. Peer Reviewed. http://escholarship.org. Retrieved 20/03/2015.

Sheila, Flor and Javier, D. (2010). Philippine Transportation Statistics. (online) http://www.kokudokeikaku.go.jp/ wat2/22_philippines.pdf. Retrieved $21 / 05 / 2015$.

Siemens, (2014). Urban Mobility: A Tale of Two Cities. Pictures of the Future. ThE magazine for Research and Innovation. $1^{\text {th }}$ August, 2014, www.siemens.com.

Simes, Randy A. (2011).Guangzhou's Bus Rapid Transit Wins City International Transport Award. Urbancincy Media. April 8, 2011. http://www.urbancincy.com. Retrieved 25/05/2015.

The Business Times (2010). Singapore sounds out oil Firms on ultra-low sulphur petrol, diesel. Eco-Business. 14 September, Singapore. http://www.eco-business.com.

Timilsina, G. R. and A. Shrestha (2009). Why have CO2 emissions increased in the transport sector in Asia? Underlying factors and policy options. Policy Research Working Paper 5098. Environment and Energy Team, Development Research Group, World Bank. https://openknowledge.worldbank.org. Retrieved 20/04/2015.

Toda, T. (2008). Public transport II, The study of master plan on comprehensive urban transport in Vientiane, capital in Lao PDR. A presentation by Japan International Cooperation Agency Katahira \& Engineering International. April 2008. http://www.unep.org. Retrieved 20/04/2015.

Truc, Mai Ai. (2003) 'National strategy for Environmental Protection until 2020 and Vision Toward 2020. Government Decision 256/2003/QD-TTg of December $2^{\text {nd }}, 2003$. Hanoi, Vietnam. http://theredddesk.org.

Tseu, Lawrence. (2006). Urban Transport Growth: The Challenges Ahead - the New Realism and Institutional Changes. Presented at the Fourth Sabah-Sarawak Environmental Convention, Malaysia, 2006. http://ww2.sabah.gov.my.

UNDESA. (2012). Sustainable Urban Transport. Shanghai Manual: A Guide for Sustainable Urban Development in the 21 st Century. United Nations Department of Economic and Social Affairs. P. 18. https://sustainabledevelopment.un.org.

Ved, Mahendra. (2012). Indian car sector booms but transport infrastructure lags. East Asian Forum. $7^{\text {th }}$ February, 2012. (online) http://www.eastasiaforum.org. Retrieved 16/02/2015.

Weixaio, Chen. (2009). Megacities Must Tie Clean Air Goals to Carbon Cuts, says experts. Sci. Dev Net, News 09/11/2009. http://www.scidev.net/global/energy/news. Retrieved 17/02/2015.

Welle, Ben. (2014). Safer cities for the Asian Century. The City Fix. World Resources Institute, Brasil. October $28^{\text {th }}$, 2014. (online) http://thecityfix.com/blog/. Retrieved 20/05/2015. 
Zahid Sultan, Nuhu H. Tini \& Mehdi Moeinaddini

Exploring the Implementation and Success of Green Urban Mobility in Asian Cities

World Bank (2010). Carbon Emissions from Transport Sector in Vietnam Remain High. The World Bank News. (online) http://beta.worldbank.org/news/. Retrieved 24/05/2015.

WHO. (2015). Urban population growth: Situation-trends. Global Health Observatory (GHO) data. World Health Organization. (online) http://www.who.int/gho/ .

WSJ. (2015). Jakarta Wins Top Spot for Worst Gridlock, Indonesia Real Time. The WallStreet Journal, South East Asia. February $4^{\text {th }}$ 2015. http://blogs.wsj.com.

Yulin,J. and Zhenyu , L. (2010). Practices and Policies of Green Urban Transport in China. Journeys: Sharing Urban Transport Solutions, Issue 4/ May 2010. Land Transport Authority Academy, Singapore http://www.lta.gov.sg/ltaacademy/doc/ Retrieved 19/04/2015. 